\title{
PRAANGGAPAN PENYIDIK DALAM INTERVIU INVESTIGATIF (KAJIAN LINGUISTIK FORENSIK DALAM PENYUSUNAN BERITA ACARA PEMERIKSAAN)
}

\author{
Sarma Panggabean ${ }^{1}$ dan T. Silvana Sinar ${ }^{2}$ \\ Universitas Sumatera Utara \\ Dosen di Universitas HKBP Nommensen-Medan dan mahasiswa program doktor \\ pasca sarjana Universitas Sumatera Utara, Guru Besar Universitas Sumatera Utara \\ Program Studi Linguistik.
}

\begin{abstract}
ABSTRAK
Penelitian ini menerapkan pendekatan deskriptif yang menetapkan persyaratan bahwa suatu penelitian harus dilakukan atas dasar fakta yang ada. Penelitian ini bertujuan mengkaji praanggapan yang muncul daripada pertanyaan yang disampaikan penyidik Dalam pendeskripsian fenomena, digunakan metode kualitatif sebagai acuan utama dalam konteks kasus wacana, bukan hanya beriorientasi interpretatif tetapi juga mampu membaca interogasi teks (textual interrogation). Data penelitian ini diperoleh daripada para penyidik kepolisian negara Republik Indonesia Resort Galang JliaituPerintis Kemerdekaan Galang, Kecamatan GalangdanKabupaten Deli Serdang. Data utamanyaialah data lisan berupa kalimat pertanyaan dan respon daripada seorang penyidik terhadap terperiksa dalam pola operandi kasus kriminal. Data lisan berasal daripada tiga orang penyidik dengan masing-masing perangkat terperiksa. Dalam hal ini, tidak hanya data lisan yang dipergunakan, juga data tulis yang bersumber dari dokumen legal kepolisian berbentuk BAP (Berita Acara Pemeriksaan Saksi, Tersangka, dan Korban).Hasilnya, mengenai respon yang diberikan terperiksa terhadap pertanyaan yang diajukan penyidik, tidak ada teori tertentu karena jawaban yang diberikan tergantung pada tipe pertanyaan penyidik. Respon yang diberikan dapat berupa respon verbal yaitu tuturan namun juga dapat berupa respon non-verbal yaitu anggukan atau gelengan Penggunaan pragmatik dengan konsep praanggapan dalam ihwal linguistik forensik berkaitan dengan pemerian kebenaran fisik maupun material dalam sebuah penyidikan, yang bertujuan untuk menghindari keberpihakan analisis dan kesalahan adaptasi fakta. Ini berarti bahwa tujuan akhir tidak akan berhenti terhadap menganalisis bahasa saja, tetapi lebih daripada itu sebagai bahan pertimbangan yang vital sebelum memutuskan sangkaan pelanggaran pasal oleh penyidik terhadap terperiksa.
\end{abstract}

Kata Kunci: Interviu Investigatif, Praanggapan, Linguistik Forensik.

\section{PENDAHULUAN}

Penyidik beradadi garis terdepan dalam pelaksanaan penegakan hukum, menjadi landasan utama (signifikasi urgensi) penelitian ini. Penyidik memerlukan perubahan fundamental, yang bermuara pada perubahan di sistem penyidikan. Perubahan fundamental ini juga mengalami perubahan kultur bagi penegak hukum di lapangan, sehingga diperlukan upaya-upaya dalam peningkatan kemampuan, kecakapan dan kemahiran daripada penyidik.

Beberapa hasil wawancara dengan penyidik Polsek Galang, mereka mengeluhkan seringnya berkas BAP yang telah diserahkan kepada Jaksa Penuntut Umum (JPU) ditolak (istilah P19). Lebih lanjut, penyidik menerangkan penolakan BAP diakibatkan penguraian alat bukti dan kronologis peristiwa yang tidak terungkap berkesesuaian ketetapan KUHP, dengan keterangan daripada ragam pihak terperiksa, sehingga uraian yang termaktum dalam BAP masih harus dilengkapi.

Peranan bahasa dalam pengkajian hukum sudah menjadi hal yang sangat vital, tidak berlebihan jika penguasaan praanggapan dalam interviu investigatif yang ditemukan dalam penelitian ini tentunya dapat berkontribusi langsung terhadap penyidik. Kemampuan dan kecekapan praanggapan penyidik dalam setiap respon terperiksa, senantiasa diperlukan dalam memperhitungkan akan terjadinya persoalan-persoalan yang tidak dapat dihindari selama proses penyidikan. Lebih lanjut, McMenamin menyatakan pragmatik penting dalam tujuan forensik karena penutur dan penulis tidak selalu dapat 
memasangkan perkataan mereka dengan makna yang ingin mereka sampaikan. Dikarenakan petutur dan pembaca mungkin saja gagal dalam memasangkan ungkapan dengan makna yang dimaksud. Makna yang dimaksud oleh penutur atau penulis lebih terbuka terhadap bagaimana petutur atau pembaca menginterpretasikan yang terkadang berakibat terjadinya kesalahpahaman pemaknaan yang memicu konflik. Batasan pragmatik berkaitan pada aturan-aturan pemakaian bahasa mengenai bentuk dan makna yang berhubungan dengan maksud pembicara, konteks dan keadaan.

Dalam pendekatan praanggapan dengan prespektif linguistik forensik, ditemukan setiap elemen dalam bahasa tidak hanya memiliki makna tetapi juga memiliki kebenaran, baik itu positif maupun negatif. Perlu dicatat, pemetaaan praanggapan penyidik dalam interviu investigatif berdasarkan kajian linguistik forensik mampu mengungkapkan sikap positif dan sikap negatif daripada suatu ungkapan atau pesan baik lisan maupun tulisan yang terealisasi dalam penggunaan bahasa. Ini berarti bahwa tujuan akhir tidak akan berhenti terhadap menganalisis bahasa saja, tetapi lebih dari itu sebagai bahan pertimbangan yang vital sebelum memutuskan sangkaan pelanggaran pasal oleh penyidik terhadap tersangka.

\section{LANDASAN TEORI}

\section{Linguistik Forensik}

Beragam aksi kejahatan umumnya melibatkan bahasa, baik daripada sisi pelaku, korban maupun saksi. Keadaan ini tentunya mempengaruhi praktek bahasa investigasi yang dilakukan oleh penegak hukum mulai dari penyidik hingga proses peradilan yang melibatkan pengacara, jaksa, dan hakim. Proses investigasi ini memiliki pola-pola praktek bahasanya sendiri, McMenamin (2002:xii) menegaskan bahwa gaya bahasa (style) merupakan refleksi daripada variasi-variasi kebahasaan personal, kelompok dan masyarakat tertentu. McMenamin (2002:67) menjelaskan definisi linguistik forensik "Forensic linguistics is the scientific study of language as applied to forensic purposes and contexts" sebagai studi ilmiah yang baru dalam keilmuan linguistik, lebih lanjut lagi McMenamin (2002: 67) menyatakan "It is a very new area of linguistics vis-à-vis its 2400-year history and is a recent and rapidly growing area of modern applied linguistics".

Ruang lingkup yang menjadi perhatian utamadalam linguistik forensik ialah: (1) bahasa daripada dokumen legal, (2) bahasa daripada polisi dan penegak hukum, (3) interview dengan anakanak dan saksi-saksi yang rentan dalam sistem hukum, (4) interaksi dalam ruang sidang, (5) bukti-bukti linguistik dan kesaksian ahli dalam persidangan, (6) kepengarangan dan plagiarisme, serta (7) fonetik forensik dan identifikasi penutur (Coulthard dan Johnson, 2007).

\section{Praanggapan (Presuppotion)}

Praanggapan (presuposisi) berasal daripada kata to pre-suppose, yang dalam bahasa Inggeris berarti to suppose beforehand (menduga sebelumnya), dalam arti sebelum pembicara atau penulis mengujarkan sesuatu ia sudah memiliki dugaan sebelumnya tentang kawan bicara atau hal yang dibicarakan. Menurut Chaer (1995:32), praangapan atau adalah "pengetahuan" yang dimiliki oleh penutur dan lawan tutur yang melatarbelakangi suatu tindak tutur. Praanggapan (presuposisi) sudah diasosiasikan dengan pemakaian sejumlah besar kata, frasa, dan struktur (Yule, 2006:46). Selanjutnya Yule (2006) mengklasifikasikan praanggapan dalam 6 jenis praanggapan, yaitu:

1. Praanggapan Eksistensial (existensial presupposition)

2. Praanggapan Faktif (factivepresupposition)

3. Praanggapan Leksikal (lexical presupposition)

4. Praanggapan Non-faktif (non-factive presupposition)

5. Praanggapan Struktural (structural presupposition)

6. Praanggapan konterfaktual (counter-factual presupposition)

\section{METODE PENELITIAN}

Penelitian ini menerapkan pendekatan deskriptifyang menetapkan persyaratan bahwa suatu penelitian harus dilakukan atas dasar fakta yang ada (Sudaryanto, 2015). Dalam pendeskripsian fenomena, digunakan metode kualitatif sebagai acuan utama dalam konteks kasus wacana, bukan hanya beriorientasi interpretatif tetapi juga mampu membaca interogasi teks (textual interrogation), logika, 
perilaku, dan fakta teoretis untuk mengungkap sebuah kebenaran dalam rentang objektivitas yang memadai (lihat Miles, 2014; bd Sudaryanto, 2015).

Data utama dalam penelitian ini adalah kalimat berupa pertanyaan dan respon daripada seorang penyidik terhadap terperiksa dalam pola operandi kasus kriminal. Data lisan ini diperoleh melalui observasi peneliti dengan sumber data pada proses penyidikan berlangsung. Data lisan berasal daripada tiga orang penyidik dengan masing-masing perangkat terperiksa. Dalam hal ini, tidak hanya data lisan yang dipergunakan, data tulis yang bersumber daripada dokumen legal kepolisian berbentuk BAP juga menjadi sumber data yang sangat diperlukan. Data ini diklasifikasikan dalam kata, frasa, kalimat yang merujuk pada operandi tindak kejahatan yang bergulir. Sumber data berupa BAP tersebut terdiri atas: Berita Acara Pemeriksaan Saksi, Tersangka, dan Korban.

\section{HASIL DAN PEMBAHASAN}

\section{PRAANGGAPAN PENYIDIK DALAM INTERVIU INVESTIGATIF (KAJIAN LINGUISTIK FORENSIK DALAM PENYUSUNAN BERITA ACARA PEMERIKSAAN)}

Pada kasus pencurian yang merugikan pihak PTPN, diduga dilakukan oleh dua orang pelaku. Kedua orang terperiksa tersebutialah saudara kandung, yang berdomisili disekitaran perkebunan. Terperiksa pertama berinisial A dan kedua berinisial S. Mengenai pembahasan praanggapan yang bersumber dari interviu investigatif; Penyidik disingkat $\mathrm{P}$, dan terperiksa diduga pelaku disingkat $\mathrm{T}$.

\section{P: "Abang dalam keadaan sehat?" \\ T: "Ia, Bang"}

Praanggapan daripada pernyataan "Abang dalam keadaan sehat?" dapat disimpulkan bahwa (1) dalam proses pemeriksaan dan pengambilan BAP membutuhkan kondisi fisik yang sehat, dan (2) akan ada rentang waktu pemeriksaan yang tidak sebentar sehingga diasumsikan terperiksa dapat menyelesaikan proses pemeriksaan itu. Kata sehat juga dapat ditujukan pada kondisi mental yang baik, tidak gila atau terpengaruh obat-obatan atau minuman keras (mabuk). Oleh sebab itu penyidik menanyakan pertanyaan demikian dengan anggapan bahwa terperiksa dalam kondisi sehat dan tidak gila. Berdasarkan jawaban yang diberikan oleh terperiksa "iya, Bang", dapat disimpulkan bahwa dia mengetahui dan paham dengan kondisi kesehatan dirinya saat itu; dia mengetahui tentang proses pengambilan BAP dan durasi waktu yang (mungkin) tidak sebentar.

\section{P: "Berbicara Masih Bisa ya?" \\ T: "Tapi ngomong pelan, Bang sakit ini (menunjuk hidung yang terluka)"}

Praanggapan daripada pernyataan "Berbicara Masih Bisa ya?" dapat ditimbulkan akibat adanya kondisi (terluka) pada bagian wajah yang dimungkinkan berpengaruh pada keleluasaan bahkan kemampuan berbicara. Penyidik juga memastikan bahwa proses pemeriksaan dan pengambilan BAP tidak akan terkendala oleh keadaan fisik terperiksa. Berdasarkan jawaban terperiksa "Tapi ngomong pelan, Bang sakit ini (menunjuk hidung yang terluka)", ia sedang menerangkan keadaan fisiknya, dan juga mengharapkan rasa empati daripada penyidik terhadap kondisinya. Selain itu, terperiksa menekankan kondisi sakit yang sedang dialami dengan tujuan agar proses pengambilan BAP berjalan tenang tanpa adanya 'kekerasan' terhadapnya.

P: " Apa yang Abang curi?"

T: "Aku ga ada ambil, Bang."

P: “Ia..Ia.. Apa yang Abang ambil?

T: "Sawit, Bang."

Praanggapan daripada pernyataan di atas dapat terlihat jelas kekuatan penguasaan makna kata 'curi' dan 'ambil'. Penyidik mengikuti pola kemaknaan yang dipahami oleh terperiksa, sehingga tanpa disadari terperiksa ia mengutarakan yang dilakukan. Penyidik menggilir terperiksa jujur dengan apa yang dilakukan tanpa adanya kekerasan verbal bahkan fisik.

T: "Sekitar jam dua belas lewatlah, Bang."

P: " Jam dua belas malam atau apa ini?"

T: “malam,Bang” 
P: "Berarti masih selasa atau udah rabu, itu ya?"

T: "Ia, Bang"

Tingginya pengaruh bahasa terlihat jelas dalam percakapan penyidik dan terperiksa (di atas). Praanggapan yang muncul ketika penyidik menanyakan perbedaan waktu antaran pukul 12.00 dengan 24.00 menyimpulkan bahwa terperiksa benar mengetahui perkara tersebut dan terlibat di dalamnya. Sangkaan ini muncul dengan melibatkan waktu kejadian yang ditanyakan kepada terperiksa, ia mengetahui kronologis kejadian dengan seksama. Sementara terperiksa dengan jawaban "Sekitar jam dua belas lewatlah, Bang." ; "malam,Bang” ; "Ia, Bang” semakin menekankan bahwa keberadaannya benar pada saat terjadinya perkara dan semakin menguatkan sangkaan terhadapnya ( tanpa disadari).

P: "Abang sama siapa?"

T: "Si A. Bang."

P: "Berarti si A itulah temanmu melakukan pencurian, ya?"

$\mathrm{T}:($ diam)

Pranggapan penyidik yang menyimpulkan bahwa si terperiksa adalah benar pelaku pencurian adalah dengan mengaitkan terperiksa A yang telah menjadi tersangka sebelumnya. Keiikutsertaan teperiksa bersama si A di saat perkara terjadi semakin menguatkan alibi penyidik mengenai terlibatnya terperiksa dalam kasus pencurian tersebut. Meskipun terperiksa diam ketika secara langsung disangkakan bahwa ia melakukan pencurian bersama temannya, namun keterangannya dalam kronologis bergulirnya kejadian tidak dapat menutupi keterlibatannya.

\section{P. “ Jangan bilang ga tahu, Bang. Banyak bilang ga tahu nanti kukasih tahu Abang." \\ T: "Ia, Bang”"}

Praanggapan yang timbul daripada pernyataan penyidik "Jangan bilang ga tahu, Bang. Banyak bilang ga tahu nanti kukasih tahu Abang." Meyimpulkan bahwa terperiksa tidak jujur dan terbuka dengan keterangan yang diberikan. Penyidik menekankan kepada terperiksa bahwa ia harus memberikan pengakuan yang sejujur-jujurnya; pernyataan nanti kukasih tahu Abang bersifat ancaman akan tindakan yang siap ia terima apabila selalu berbelit-belit memberikan keterangan. Penyidik dengan sengaja menggunakan kalimat ini dilatar belakangi daripada uraian terperiksa yang semakin menutupi keberadaanya dalam perkara. Terperiksa dengan menjawab "Ia, Bang” terlihat memahami tujuan pernyataan penyidik, diperhatikan daripada uraiannya dalam pertanyaan yang dilontarkan penyidik berikutnya.

P: "Alat apa yang Abang gunakan?"

T: " Ga ada, Bang. Disuruh pegang ini saja aku, Bang”

Praanggapan yang dapat disimpulan bahwa penyidik semakin dalam menggali informasi mengenai keterlibatan terperiksa dalam kasus pencurian tersebut. Penggunaan alat dalam kasus ini menjadi alat bukti yang kuat dalam mendukung tindakan terperiksa. Akan tetapi hal tersebut nampaknya dapat dipahami terperiksa sehingga ia mengatakan ga ada...disuruh..saja. Hal ini menghindarikan terperiksa daripada dugaan sebagai pelaku utama kasus pencurian di perkebunan milik negara ini.

P: “Jadi, Abang.. Apa yang abang lakukan di situ?"

T: "Ga ada, Bang. Cuma tungguin motor saja, kakikupun sakit."

Penyidik menyampaikan pertanyaan yang menjurus pada dalamnya keterlibatan terperiksa dalam kasus ini. Apa yang abang lakukan di situ? Menginginkan jawaban yang lebih rinci mengenai tindakan terperiksa, tetapi terperiksa tetap mengelak sangkaan terlibatnya dengan mengatakan $g a$ ada..Cuma tungguin motor..kaki sakit dengan menyimpulkan anggapan akan memupuskan dugaan keterlibatanya dalam tindak perkara ini.

\section{P: “ Jago kali Abang ngarang” \\ T: "(Diam)"}

Praanggapan penyidik menyimpulkan kebohongan yang sedang terperiksa uraian kepadanya. Ketidaktepatan pernyataan terperiksa disimbolkan penyidik dengan ucapan jago mengarang hal ini menandakan bahwa penyidik mensinyalir unsur ketidakbenaran dalam ucapan terperika. Posisi diam (tanpa komentar) daripada penyidik menyiaratkan bahwa ia juga memahami ketidakjujurannya dalam memberikan jawaban. 
P: "Abang waras, kan?”

T: "Waras."

Penyidik tidak sedang menanyakan kondisi mental terperiksa, tetapi menekankan bahwa penyidik benar-benar mengetahui kebohongan dalam uraian terperiksa. Kata waras menekankan bahwa ketarangan terperiksa jauh daripada logika umum yang ada. Terperiksa semakin jauh daripada kejujuranya dan berusaha menutupinya dengan mengiakan ucapan penyidik (jawaban waras).

P: “Ia, itukan bukan ladang Abang?”

T: "Ia, Bang."

Praanggapan yang dapat disimpulkan bahwa tindakan terperiksa tersebut adalah pencurian, sebab mengambil barang orang lain. Bukan ladangabang menekankan tindakan terperiksa yang salah telah mengambil sawit bukan di ladangnya. Jawaban terperiksa dapat memperkuat sangkaan penyidik terhadapnya, sebab tidak ada jawaban yang menyiaratkan bahwa ia hanya mengambil barangnya (dalam hal ini sawit) sendiri, bukan milik pihak lain.

P: "Abang ngapaen saja?"

T: "Ga ada, Bang. Ga ada melawan aku."

P: "Napa muka macam cendol begini?"

Praanggapan penyidik menyimpulkan bahwa terperiksa berniat melawan atau berusaha melarikan diri pada saat pihak keamanan mengetahui tindakannya. Akan tetapi terperiksa mengelak tuduhan tersebut ga ada...ga ada melawan..ia berusahan berbohong dan menyatakan sikap kooperatifnya di lapangan. Penyidik tidak meyakini ucapan terperiksa bahkan ia menunjukkan kondisi berlawanan muka macam cendol terperiksa. Terperiksa semakin tersudut dengan ketidakjujurannya.

P: "Abang ngapaen saja?”

T: "Cuma duduk saja, Bang. Ga ada ngapain , Bang."

P: " Cuma duduk saja? Terbuka saja , Bang."

T: "Ia, Bang. Duduk saja, Bang.”

P: " Jadi ngapain abang ikut kalau cuma duduk saja?"

T: “ (diam)

Praanggapan penyidik dapat disimpulkan bahwa terperiksa telah berbohong dalam penyampaian uraiannya Cuma duduk saja.. ga ngapain.. tetapi penyidik tidak meyakini ucapan itu dan melotarkan sebuah pertanyaan yang tidak membutuhkan jawaban daripada terperiksa ..ngapain ikut kalau cuma duduk saja. Terperiksa hanya diam dan (mungkin) menyadari kekeliruan keterangan yang ia sampaikan.

P: "Abang ga tahu?"

T: "Ga tahu, Bang kalau muat buah, Bang."

P: "Abang lihat dia muatbuah?"

T: "Lihat, Bang."

P: "Ga ada Bang bantuin?"

T: "Ga ada Bang”"

P: " Ga ada? Lihat saja? Diam saja?

T: “(Diam)”

Praanggapan penyidik menyimpulkan bahwa terperiksa terlibat (ambil bagian) dalam kasus ini. Sanggkaan keterlibatan akan memberatkan sanksi yang diterima. Hal ini dipahami oleh teperiksa sehingga ia selalu menyangkal keterlibatannya ga tahu..ga ada..(diam). Akan tetapi penyidik sama sekali tidak percaya dengan keterangan itu dengan ucapan " Ga ada? Lihat saja? Diam saja? Semakin menunjukkan pemahaman penyidik bahwa terperiksa sedang berbohong.

P: “ Dari mana (alat) itu? Sudah disiapkan? Dari rumah siapa diambil?

T: "Sudah ada di motor."

Pranggapan penyidik menyimpulkan sangkaan bahwa tindakan pencurian ini telah direncakan sebelumnya. Penyediaan alat dalam tindakan pidana menyiaratkan perencanaan akan tindakan yang akan dilakukan. Hal ini semakin memberatkan tersangka dalam tuduhannya. Jawaban terperiksa sudah ada di motor menyimpulkan pemahaman terperiksa akan tindakannya. Ia menghindar daripada 
sangkaan ikut merencanakan pencurian itu sebelumya. Tentunya hal ini terwujud jika penyidik memiliki keyakinan yang sama dengan terperiksa.

P: "Sudah berapa lama kenal A?

T: "itu adek, Bang."

P: "Adek kandung?"

T: "Ia, Bang."

P: "Berarti abang ditumbalkan sama adek?"

T: "Ga tahulah, Bang, beginilah ceritanya."

Praanggapan penyidik yang semakin menarik dalam simpulannya adalah ketika ia memilih diksi ditumbalkan sama adek. Menyiaratkan bahwa kasusnya terjadi akibat kelalaiannya sendiri. Ketidakterlibatannya dalam perencanaan tindak pencurian dapat diperhatikan daripada ucapannya menyampaikan kronologis perkara. Terperiksa merasa menyesal dengan tindakannya " Ga tahulah, Bang, beginilah ceritanya." Ia tidak menduga akan terlibat dalam perkara tersebut dan berurusan dengan pihak penegak hukum. Penyesalannya terlihat daripada raut wajahnya dan terdengar ucapannya.

\section{KESIMPULAN}

Penelitian ini mengkaji praanggapan yang muncul daripada pertanyaan yang disampaikan penyidik. Untuk kajian pertama, ditelaah pertanyaan yang disampaikan penyidik kepada terperiksa. Mengenai respon yang diberikan terperiksa terhadap pertanyaan yang diajukan penyidik, tidak ada teori tertentu karena jawaban yang diberikan tergantung pada tipe pertanyaan penyidik. Respon yang diberikan dapat berupa respon verbal yaitu tuturan namun juga dapat berupa respon non-verbal yaitu anggukan atau gelengan. Berkenaan dengan praanggapan, disimpulkan bahwa ada beberapa praanggapan yang terkandung dalam pertanyaan penyidik dikonfirmasi oleh terperiksa namun juga ada yang ditolak oleh terperiksa. Kemahiran penyidik menggiring terperiksa dalam proses interviu investigatif akan menghasilkan dua perkara yang sahih dan berkekuatan hukum yang tepat.

\section{RUJUKAN}

Coulthard, M.\& Johnson, A. 2007. An Introduction to Forensic Linguistics:Language in Evidence. London: Routledge.

Coulthard, Malcom dan Johnson, Alison. 2007. An Introduction to Forensic Linguistics, Language in Evidence. New York: Routledge Taylor \& Francis Group.

Gibbons, Jhon. 2007. Forensik Linguistics, an Introduction to Language in the Justice System. Oxford: Blackwell Publishing.

Hartini, L. 2010. "Penerapan Fonetik Akustik dan Teori Grice pada Rekaman Penyadapan Telepon sebagai Alat Bukti Hukum: Kajian Linguistik Forensik terhadap Percakapan Antara Artalyta Suryani dengan Jaksa Urip Tri Gunawan” dalam Jurnal Wawasan Hukum, Vol. 23 No. 02 September 2010.

Hill, Carole, Memon, Amina \& McGeorge, Peter. 2008. The Role of Confirmation Bias in Suspect Interviews: A Systematic Evaluation. Legal and Criminological Psychology (2008), 13, 357-371. The British Psychological Society.

McMenamin, G. 2002. Forensic Linguistics: Advances in Forensic Stylistics. London: CRC Press.

Miles, Matthew B, A. Michael Huberman. 2014. Qualitative Data Analysis a Methods Sourcebook. United State of America: SAGE Publications.

Sudjana, Eva T. S. dan Nurul F. 2013. "Kurt Cobain's Suicide Note Case: Forensic Linguistic Profiling Analysis" in International Journal of Criminologyand Sociological Theory, Vol. 6, No. 4, December 2001.

Sudaryanto. 2015. Metode dan Aneka Teknik Analisis Bahasa. Yogyakarta: Sanata Dharma University Press.

Yeschke, Charles L. 2003. The Art of Investigative Interviewing: A Human Approach to Testimonial Evidence (second edition). USA: Elsevier Science.

Yule, G. 2006. Pragmatik. Penerjemah Wahyunu Indah Fajar. Yogyakarta: Pustaka Pelajar.

Kitab Undang-undang Hukum Acara Pidana 